\title{
Research Article: Nutritional quality of dehydrated spine gourd (Momordica dioca L.) slices as influenced by drying methods
}

A.M. SONKAMBLE, K.S. GIRI AND S.R. PATIL

Article Chronicle: Received :

10.07.2017;

Accepted :

23.07.2017

KEY Words:

Spine gourd, Solar drying, Cabinet drying, Nutritional quality
SUMMARY : An investigation was conducted in the year 2016-2017 to evaluate nutritional quality of dehydrated spine gourd (Momordica dioca L.) slices as influenced by drying methods. Spine gourd is very nutritive vegetable available in market for very short period.The selected spine gourd fruits were cut manually with stainless steel knife and $0.5 \mathrm{~cm}$ thick slices were prepared. Slices were allowed for pre-treatments and blanching was carried out in boiling water for 3 minutes. The spine gourd slices were dried by solar and cabinet dryers and observations were recorded upto storage period of six month at ambient conditions. Solar drying was found superior and exhibited maximum dehydration and rehydration ratio, ascorbic acid, crude protein content, carbohydrate content and crude fibre content with minimum moisture and titrable acidity content as compared to cabinet drying. Solar dried slices maintained good nutritional status of dehydrated spine gourd slices during storage period.

How to cite this article : Sonkamble, A.M., Giri, K.S. and Patil, S.R. (2017). Nutritional quality of dehydrated spine gourd (Momordica dioca L.) slices as influenced by drying methods. Agric. Update, 12(TECHSEAR-2) : 379-381; DOI: 10.15740/HAS/AU/12.TECHSEAR(2)2017/379-381.

Author for correspondence :

\section{A.M. SONKAMBLE}

Department of

Horticulture, Dr.

Panjabrao Deshmukh

Krishi Vidyapeeth,

AKOLA (M.S.) INDIA

Email:arvind.pdkv@

gmail.com

See end of the article for

authors' affiliations 